\title{
EVALUATION OF DEMOGRAPHIC DATA OF KEBBI STATE NORTH- WEST NIGERIA USING THE NIGERIAN CENSUS
}

\author{
Gerald Onwuka $^{1}$, Wasiu Babyemi ${ }^{2}$, Sophia Ajala ${ }^{3}$ and Basiru Shehu ${ }^{4}$ \\ Dr. of Statistics \\ ${ }^{1}$ Department of Mathematics \\ Kebbi State University of Science and Technology, \\ Aliero \\ Dr. of Statistics \\ ${ }^{2}$ Department of Mathematics \\ Kebbi State University of Science and Technology, \\ Aliero \\ ${ }^{3,4}$ Department of Mathematics \\ Kebbi State University of Science and Technology, \\ Aliero \\ Corresponding Author Email: bsbshehu0@ gmail.com
}

\begin{abstract}
In most of the censuses conducted in different countries reports on age are subject to errors arising from a variety of causes. These include deliberate misstatement, tendency to report ages ending in certain preferred digits and to avoid others, exaggeration of age at older ages, carelessness in reporting, ignorance of correct age, fear, superstition, anticipation of benefits of unfavourable end points, ignorance of date of birth, lead to the poor age estimation. However, this study aimed at using the agesex data from 2006 Nigeria population census, where the result shows poor in data quality as a result of age misreporting and age heaping. More female are affected with age heaping and lack of educational background in all levels of education attainment. Finally, female population out number that of male in the state. There is a tendency of age heaping with terminal digits ' 0 ' and ' 5 ' indicating preference for such ages, therefore people with terminal digit 7 and 8 are more reliable.
\end{abstract}

Keywords: Census, Whipple's Index, Myers's Blended Method, Age, Sex-ratio

\section{INTRODUCTION}

\section{Background of the Study}

Literally translated from Greek, 'Demography' means 'statistical data of about the characteristic of a population such as age, gender, and income of the people within the population.

Demographic data are used for planning, policy formulation, and implementation as well as in programme monitoring. The quality of the data from estimates of demographic parameters require for this purpose depends on the quality of the data from which they are derived. Age and sex are two items on the bases of which data are always collected, tabulated, analysed and adjusted in all demographic enquiries. (Ramachandran,1989). Census data are normally used 
for reapportionment purposes. However, for some cases when census data were obsolete, estimated population figures were used for reapportionment. For example, in 1988 inter-censal population estimates were used for redistricting Palm Beach County, Florida and in 1991 Los Angeles County, California, used population estimates for redistricting purposes. Serow et al. (1997).

In most of the censuses conducted in different countries reports on age are subject to errors arising from a variety of causes. These include deliberate misstatement, tendency to report ages ending in certain preferred digits and to avoid others, exaggeration of age at older ages, carelessness in reporting, ignorance of correct age, fear, superstition, anticipation of benefits of unfavourable end points, ignorance of date of birth, lead to the poor age estimation, Nwogu et al. (2006). When ages are estimated the problem of digits preference and other age misstatements are unavoidable in most of the cases due to the above mention factors. These influence the researcher to use age preference index and other criteria to judge 2006 Nigerian census data in Kebbi State.

The aim of this study is provide essential information by evaluating a demographic data in Kebbi State using latest (2006) population census in Nigeria. There were numbers of objectives we wish to achieve such as to use Index age preference and Whipple index to detect age heaping in 2006 censuses, to employ United Nations Age-Sex accuracy Index for 2006 censuses and evaluate the accuracy in five year age group, to employ Masculinity Proportion to determine the ratio of male per female educational status, to use Myers's Blended Index in taking the aggregate population of each age ending in digits 0 to 9, to construct the Ratio of the Excess or Deficit of males to the total population in 21 local government area of Kebbi State.

\section{MATERIALS AND METHOD}

\subsection{DATA FRAME}

Nigerian National Population Commission census 2006 data was used to discuss the current status of age-sex data quality and ratio of male to female population and educational status rate in the Kebbi state. The data are on the distribution of household population by sex and age in single years and five-year age groups.

The data was analysed using the following methods as considered and used by many demographic researchers:

i. Indexes of Age Preference considering (age 20 and 30) only.

ii. Whipple's Index considering ages (with terminal digits as 0, 5 and 0, 5 respectively, within the limit of 23 to 62 years)

iii. Myers's Blended Index (taking the aggregate population of each age ending in digits 0 to 9)

iv. United Nations age and sex accuracy Index, known as Joint Score (JS) will be apply to analyse the data by five year age groups.

v. The Masculinity Proportion to determine the ratio of males to females educational status

vi. The Ratio of the Excess or Deficit of Males to females in the total population

\subsection{ERRORS IN SINGLE YEARS OF AGE}


Trying to analyse errors in single years of age the following methods were employed:

i. Indexes of Age Preference

ii. Whipple's Index

iii. Myers's Blended Method (Myers's Index)

2.2.1. Indexes of Age Preference: Measures the biasness of age and digit preference reported particularly in a single age of the years. However, any year can be use or assign in order to evaluate the percentage of heaping on that age. It is given as

$$
\begin{aligned}
& \mathrm{IP}_{20}=\frac{\mathrm{P}_{20}}{\frac{\mathrm{P}_{18}+\mathrm{P}_{19}+\mathrm{P}_{20}+\mathrm{P}_{21}+\mathrm{P}_{22}}{5}} \times 100 \\
& \mathrm{IP}_{30}=\frac{P_{30}}{\frac{P_{29}+P_{30}+P_{31}}{3}} \times 100
\end{aligned}
$$

\subsubsection{Whipple measure}

Whipple index is one of the widely used indexes to measure age misreporting. The index was invented by the American demographer George C. Whipple (1866-1924).

Whipple measure was designed to evaluate the magnitude of the heaping at age with terminal digits as 0 and 5 with the ages ranging from 23 to 62 . For example 25, 35, 45, 55, have their terminal digits as 5 and 30, 40, 50, 60 are the ages with terminal digits as 0 .

The index is basically a percentage of sums of population corresponding to ages ending with 0 and or 5 among the average of the population between the ages 23 to 62 . Whipple index is given as:

$$
\begin{aligned}
& W I_{0}=\frac{P_{30}+P_{40}+P_{50}+P_{60}}{1 / 10\left(P_{23}+P_{24}+P_{25}+\ldots+P_{61}+P_{62}\right)} * 100 \\
& W I_{5}=\frac{P_{25}+P_{35}+P_{45}+P_{55}}{1 / 10\left(P_{23}+P_{24}+P_{25}+\ldots+P_{61}+P_{62}\right)} * 100 \\
& W I_{0,5}=\frac{P_{25}+P_{30}+P_{35}+\ldots+P_{55}+P_{60}}{1 / 5\left(P_{23}+P_{24}+P_{25}+\ldots+P_{61}+P_{62}\right)} * 100 \\
& W I 0,5=\frac{\sum_{25}^{60} \text { Population of ages ending in } 0 \text { or } 5}{\frac{\sum_{23}^{62} \text { Population }}{5}} * 100
\end{aligned}
$$

The choice of the range 23 to 62 is largely arbitrary. In computing indexes of heaping, the ages of childhood and old age are often excluded because they are more strongly affected by other types of errors of reporting than by preference for specific terminal digits.

WI varies from 100 to 500 with 100 representing no heaping or no preference on the digits 0 and 5 and 500 indicates extreme heaping only on the basis of two digits 0 and 5 . 
Table 1: Range of Reliability for Whipple index

\begin{tabular}{|c|c|c|}
\hline Quality of the data (Interpretation) & Whipple index & Deviation from the perfect \\
\hline Highly Accurate & $<=105$ & $<5 \%$ \\
\hline Fairly Accurate & 105 to 109 & $5-9.99 \%$ \\
\hline Approximate & 110 to 124.9 & $10-24.99 \%$ \\
\hline Rough & 125 to 174.9 & $>=75 \%$ \\
\hline Very Rough & $>=175+$ & \\
\hline
\end{tabular}

\subsubsection{Myers's Blended Method (Myers's Index)}

Myers' method also measures preferences for each of the ten possible digits and proposes a blended index. It is based on the principle that in the absence of age heaping, the aggregate population of each age ending in one of the digits 0 to 9 should represent $10 \%$ of the total population. The index is calculated by summing the number of people whose age ends with a particular digit for the population aged 10 and over, and then for the population aged 20 and over. Each series is then weighted and the results are added to obtain a blended population. Myers's blended index is obtained by summing the absolute deviations between the aggregate and theoretical distributions (10\%).

The following steps should be followed to calculate the Myers's Blended Method:

Step1: Classify the population against the ages ending with preferred digit and take the sum of the of the first nine population values in one column and from the second to ninth population in the second column.

Table 2: Step 1, population classification

\begin{tabular}{|c|c|c|c|}
\hline Terminal & $\begin{array}{c}\text { Population of each terminal digit } \\
\text { as per column (1) }\end{array}$ & \multicolumn{2}{|c|}{$\begin{array}{c}\text { Summing the population with } \\
\text { terminal digit }\end{array}$} \\
\cline { 3 - 4 } & & $\begin{array}{c}\text { Sum of each row } \\
\text { from } 1 \text { to } 9\end{array}$ & $\begin{array}{c}\text { Sum of each } \\
\text { row from } 2 \text { to } \\
9\end{array}$ \\
\hline$(1)$ & & $(2)$ & $(3)$ \\
\hline 0 & & $\mathrm{X}_{0}$ & $\mathrm{Y}_{0}$ \\
\hline 1 & $\mathrm{P}_{10}, \mathrm{P}_{20}, \mathrm{P}_{30} \ldots \mathrm{P}_{90}$ & $\mathrm{X}_{1}$ & $\mathrm{Y}_{1}$ \\
\hline 2 & $\mathrm{P}_{11}, \mathrm{P}_{21}, \mathrm{P}_{31} \ldots \mathrm{P}_{91}$ & $\mathrm{X}_{2}$ & $\mathrm{Y}_{2}$ \\
\hline 3 & $\mathrm{P}_{12}, \mathrm{P}_{22}, \mathrm{P}_{32} \ldots \mathrm{P}_{92}$ & $\mathrm{X}_{3}$ & $\mathrm{Y}_{3}$ \\
\hline 4 & $\mathrm{P}_{13}, \mathrm{P}_{23}, \mathrm{P}_{33} \ldots \mathrm{P}_{93}$ & $\mathrm{X}_{4}$ & $\mathrm{Y}_{4}$ \\
\hline
\end{tabular}




\begin{tabular}{|c|c|c|c|}
\hline 5 & $\mathrm{P}_{15}, \mathrm{P}_{25}, \mathrm{P}_{35} \ldots \mathrm{P}_{95}$ & $\mathrm{X}_{5}$ & $\mathrm{Y}_{5}$ \\
\hline 6 & $\mathrm{P}_{16}, \mathrm{P}_{26}, \mathrm{P}_{36} \ldots \mathrm{P}_{96}$ & $\mathrm{X}_{6}$ & $\mathrm{Y}_{6}$ \\
\hline 7 & $\mathrm{P}_{17}, \mathrm{P}_{27}, \mathrm{P}_{37} \ldots \mathrm{P}_{97}$ & $\mathrm{X}_{7}$ & $\mathrm{Y}_{7}$ \\
\hline 8 & $\mathrm{P}_{18}, \mathrm{P}_{28}, \mathrm{P}_{38} \ldots \mathrm{P}_{98}$ & $\mathrm{X}_{8}$ & $\mathrm{Y}_{8}$ \\
\hline 9 & $\mathrm{P}_{19}, \mathrm{P}_{29}, \mathrm{P}_{39} \ldots \mathrm{P}_{99}$ & $\mathrm{X}_{9}$ & $\mathrm{Y}_{9}$ \\
\hline
\end{tabular}

Step2: assign the weight to each $X^{\prime}$ 's from 1-9 and Y's in the reverse order to that of the X's that is from 9-1 to calculate the blended population given as

$B i=i * X_{i}+(10-i) * Y_{j}$

Table: 3: Step 2, Blended population

\begin{tabular}{|c|c|c|c|c|c|}
\hline $\begin{array}{c}\text { Preferred } \\
\text { age }\end{array}$ & $\begin{array}{c}\text { Sum of } \\
\text { first (1-9) }\end{array}$ & $\begin{array}{c}\text { Sum of second } \\
(2-9)\end{array}$ & Weight for X & Weight for Y & $\begin{array}{c}\text { Blended } \\
\text { Population }\end{array}$ \\
\hline 0 & $\mathrm{X}_{0}$ & $\mathrm{Y}_{0}$ & 1 & 10 & $1 * \mathrm{X}_{0}+10^{*} \mathrm{Y}_{9}$ \\
\hline 1 & $\mathrm{X}_{1}$ & $\mathrm{Y}_{1}$ & 2 & 9 & $2 * \mathrm{X}_{1}+9^{*} \mathrm{Y}_{8}$ \\
\hline 2 & $\mathrm{X}_{2}$ & $\mathrm{Y}_{2}$ & 3 & 8 & $3 * \mathrm{X}_{2}+8^{*} \mathrm{Y}_{7}$ \\
\hline 3 & $\mathrm{X}_{3}$ & $\mathrm{Y}_{3}$ & 4 & 7 & $4 * \mathrm{X}_{3}+7 * \mathrm{Y}_{6}$ \\
\hline 4 & $\mathrm{X}_{4}$ & $\mathrm{Y}_{4}$ & 5 & 6 & $5 * \mathrm{X}_{4}+6^{*} \mathrm{Y}_{5}$ \\
\hline 5 & $\mathrm{X}_{5}$ & $\mathrm{Y}_{5}$ & 6 & 5 & $6 * \mathrm{X}_{5}+5^{*} \mathrm{Y}_{4}$ \\
\hline 6 & $\mathrm{X}_{6}$ & $\mathrm{Y}_{6}$ & 7 & 4 & $7 * \mathrm{X}_{6}+4 * \mathrm{Y}_{3}$ \\
\hline 7 & $\mathrm{X}_{7}$ & $\mathrm{Y}_{7}$ & 8 & 3 & $8 * \mathrm{X}_{7}+3 * \mathrm{Y}_{2}$ \\
\hline 8 & $\mathrm{X}_{8}$ & $\mathrm{Y}_{8}$ & 9 & 2 & $9 * \mathrm{X}_{8}+2 * \mathrm{Y}_{1}$ \\
\hline 9 & $\mathrm{X}_{9}$ & $\mathrm{Y}_{9}$ & 10 & 1 & $10 \mathrm{X}_{9}+1^{*} \mathrm{Y}_{0}$ \\
\hline
\end{tabular}

Step3: To calculate the percentage of the population at each preferred digit after calculating the Grand Blended Population and obtain the magnitude of the preferences at every terminal digits and find the absolute difference of the obtained magnitude of preference from 10.

Grand Blended population $=\sum_{i=0}^{9} B_{i}$

Magnitude of preference $=b_{i}=\left[\frac{B_{i}}{\sum_{i=0}^{9} B_{i}} * 100\right]$

Now Mayer's index is given as $M I=\sum_{i=0}^{9}\left|b_{i}-10\right|$

It is conceptually similar to Whipple`s index, except that the index considers preference (or avoidance) of age ending in each of the digits 0 to 9 in deriving overall age accuracy score.

It is based on the principle that in the absence of age heaping, the aggregate population of each age ending in one of the digits 0 to 9 should represent $10 \%$ of the population. 
The theoretical range of Myers` Index is from 0 to 90 , where 0 indicates no age heaping and 90 indicates the extreme case where all recorded ages end in the same digit.

\subsection{SEX RATIO BY AGE GROUP}

Sex ratio is particularly use in this study in order to analyse the number of males attended school per every 100 females in kebbi state using 2006 census data as well as number of birth and death rate using present data in Sir Yahaya Memorial Hospital and National Population Commission Kebbi state branch. The formula use is given as follow:

Sex Ratio, $(S R) \frac{5 P_{x}^{m}}{5 P_{x}^{f}} * 100$

i. $\quad{ }_{5} \mathrm{P}_{\mathrm{x}}{ }^{\mathrm{m}}=$ Male population enumerated in a specific age group

ii. $\quad{ }_{5} \mathrm{P}_{\mathrm{x}}{ }^{\mathrm{f}}=$ Female population e numerated in the same age group

iii. One hundred is the point of balance of the sexes according to this measure.

Table 4: Ratio Interpretation

\begin{tabular}{|l|c|}
\hline \multicolumn{1}{|c|}{ Value of sex ratio } & Interpretation \\
\hline A sex ratio $=100$ & Same number of men and women in a given age group \\
\hline A sex ratio above 100 & Denotes an excessof malesin a given age group \\
\hline $\begin{array}{l}\text { A sex ratio below } \\
100\end{array}$ & Denotes an excess of femalesin a given age group \\
\hline
\end{tabular}

Accordingly, the greater the excess of males, the higher the sex ratio and the greater the excess of females, the lower the sex ratio.

The Masculinity Proportion: The masculinity proportion (or percentage male) is the measure of sex composition most often used. The formula for the masculinity proportion is given as

$\mathrm{MP}=\frac{P_{m}}{P_{t}} * 100$

Where $\mathrm{P}_{m}$ represents the number of males and $\mathrm{P}_{t}$ represents the total population.

\section{The Ratio of the Excess or Deficit of Males to females in the total population}

The excess (or deficit) of males as a percentage of the total population, is calculated using the following formula: $=\frac{P_{f}-P_{m}}{P_{t}} * 100$

Where $\mathrm{P}_{\mathrm{m}}$ represents the number of males, $\mathrm{P}_{\mathrm{f}}$ the number of females, and $\mathrm{P}_{\mathrm{t}}$ the total population. 


\subsection{UNITED NATION AGE-SEX ACCURACY INDEX}

The United National Age-Sex Accuracy Index also known as Joint score (JS) introduced by (Ramachandra (1989), is a single index for joint evaluation of data on age and sex proposed by the United Nation on the empirical evidence.

This index is computed as weighted sum of the United Nation Age Ratio Score (ARS) and United Nation Sex Ratio Score (SRS) of a study population. It is expressed as

is given as

$J S=A R S(M)+A R S(F)+3(S R S)$

Where the Age Ratio Score for male, ARS, is given by

$$
\operatorname{ARS}(\mathrm{M})=\frac{1}{K-3} \sum_{1=2}^{K-2}|\operatorname{AR}(\mathrm{M})(\mathrm{i})-100|
$$

The Age Ratio Score for Female, ARS (F), is given by ${ }_{n} P_{x}$

$$
\begin{aligned}
& \operatorname{ARS}(\mathrm{M})=\frac{1}{K-3} \sum_{1=2}^{K-2}|\mathrm{AR}(\mathrm{F})(\mathrm{i})-100| \\
& A R=\frac{\mathrm{nP}_{x}}{1 / 2\left(\mathrm{nP}_{x-n}+\mathrm{nP}_{x+n}\right)} * 100
\end{aligned}
$$

Where $\mathrm{nP}_{x}$ is the population aged $(\mathrm{x}$ to $\mathrm{x}+\mathrm{n})$ years

Sex Ratio Score (SRS) is given by

$$
\mathrm{SRS}=\frac{1}{K-1} \sum_{i=1}^{K}|S R(\mathrm{i})-S R(i-1)|
$$

Where $\mathrm{k}$ is the number of ages or age groups involved in the computation, SR(i) denote the sex ratio for the ith age or age group.

Table 5: United Nation Criteria for Data Quality on the Basis of Joint Score (JS)

\begin{tabular}{|c|c|}
\hline Joint Score & Quality of data interpretation \\
\hline$<20$ & Reliable \\
\hline 20 to 39 & Usable with adjustment \\
\hline 40 to 60 & Deficient and required massive adjustment \\
\hline$>60$ & Grossly erroneous and risky to utilize for any inference \\
\hline
\end{tabular}




\section{DATA ANALYSIS AND INTERPRETATION}

The presentation of data by single years of age or in age groups for males and females separately is essential in almost all types of planning, for the analysis of other types of data, for comparative studies and for the evaluation of the completeness and accuracy of the census counts of a given population. This paper took the advantage of the published data for Nigerian censuses conducted in 2006 and applied the available methods of evaluation. Indexes of Age Preference under 20 and 30, Whipple's index under 0, 5 and both 0, 5, and Myers's Blended under $0,1,2, \ldots 9$ were analysed in this chapter. Finally, calculated values of theUnited Nations Age-Sex Accuracy Index known as Joint Score (JS), Ratio of the Excess or Deficit of Females to the total population and Masculinity Proportion were analysed to take the ration of literacy and illiteracy and ration of number of excess females against male considering entire 21 Local Government in Kebbi State using 2006 census in Nigeria.

Table 6: Index Preference

\begin{tabular}{|c|c|c|c|c|}
\hline Index Preference & Male & Female & Both Sex & Interpretation \\
\hline $\mathrm{IP}_{20}$ & 234.1756 & 269.521359 & 255.0535 & Very Rough \\
\hline $\mathrm{IP}_{30}$ & 258.2739 & 267.4940898 & 263.2418 & Very Rough \\
\hline
\end{tabular}

Table 6 for Index Preference, put into consideration ages reported in kebbi state under 20 and 30 years only in order to estimate age heaping and age misreporting of males, females and both sex under such years. However, much age misreporting and age heaping occurred in females than males but result from all levels are interpreted as (very rough). Which means too much age exaggeration was narrated under age 20 and 30 .

Table 7:Whipple index

\begin{tabular}{|c|c|c|c|c|}
\hline Whipple index & Male & Female & Both Sex & Interpretation \\
\hline$W I_{0}$ & 270.2976 & 351.8413 & 346.66844 & Very Rough \\
\hline$W I_{5}$ & 188.169 & 225.7048 & 206.78335 & Very Rough \\
\hline$W I_{0,5}$ & 379.1691 & 453.6152 & 142.95891 & Very Rough \\
\hline
\end{tabular}

The Whipple indices computed for the age-sex data of 2006 Nigeria censuses, presented in Table 7; indicate patterns of digit preferences in the censuses. The indices are well above 175at all stages considered, which implies age-heaping for ages ending in 0,5 and both 0,5 occurred in excess; and this was more pronounced with the females than the males in all levels. 
Table 8:Mayers Index for Male

\begin{tabular}{|c|c|c|c|c|c|c|c|c|}
\hline \multirow[t]{2}{*}{$\begin{array}{c}\text { Terminal } \\
\text { digit }\end{array}$} & \multicolumn{2}{|c|}{$\begin{array}{l}\text { Population with } \\
\text { Terminal Digit }\end{array}$} & \multirow{2}{*}{$\begin{array}{c}\text { Ages } \\
10 \\
+(\mathrm{a}) \\
\end{array}$} & \multirow{2}{*}{$\begin{array}{l}\text { Ages } \\
20 \\
+(a) \\
\end{array}$} & \multirow[t]{2}{*}{$\begin{array}{l}\text { Blended } \\
\text { Population }\end{array}$} & \multirow[t]{2}{*}{$\begin{array}{c}(\%) \\
\text { Distribution }\end{array}$} & \multirow{2}{*}{$\begin{array}{c}\text { Deviation } \\
\text { from } \\
10 \%\end{array}$} & \multirow{2}{*}{$\begin{array}{c}\text { Absolute } \\
\text { Deviationfrom } \\
10 \%\end{array}$} \\
\hline & $\begin{array}{l}\text { Ages } 10 \\
+(a)\end{array}$ & $\begin{array}{c}\text { Ages } \\
20+(a)\end{array}$ & & & & & & \\
\hline 0 & 355,469 & 283,398 & 1 & 9 & 2906051 & 35.10356 & 25.10356 & 25.43 \\
\hline 1 & 40,782 & 19,459 & 2 & 8 & 237236 & 2.865685 & -7.13431 & 7.11 \\
\hline 2 & 82,841 & 38,798 & 3 & 7 & 520109 & 6.282642 & -3.71736 & 3.66 \\
\hline 3 & 57,581 & 25,680 & 4 & 6 & 384404 & 4.643397 & -5.3566 & 5.31 \\
\hline 4 & 39,867 & 16,050 & 5 & 5 & 279585 & 3.377239 & -6.62276 & 6.59 \\
\hline 5 & 238,207 & 177,337 & 6 & 4 & 2138590 & 25.83304 & 15.83304 & 15.14 \\
\hline 6 & 42,069 & 21,359 & 7 & 3 & 358560 & 4.331215 & -5.66878 & 5.63 \\
\hline 7 & 60,215 & 35,750 & 8 & 2 & 553220 & 6.682605 & -3.31739 & 3.26 \\
\hline 8 & 64,530 & 32,303 & 9 & 1 & 613073 & 7.405598 & -2.5944 & 2.53 \\
\hline 9 & 28,768 & 15,005 & 10 & 0 & 287680 & 3.475022 & -6.52498 & 6.49 \\
\hline Total & $1,010,329$ & 665,139 & & & $8,278,508$ & 100 & $\mathbf{0}$ & 81 \\
\hline
\end{tabular}

The Myers indices for males in kebbi state resulted as follows: more age heaping under digit 0 with (25.10) was reported, followed by digit 5 with (15.3) then digit 1 with (7.13). Digit 8 was found with lowest value (2.59) which means males with age reported as 1968, 1978, $1988 \ldots$ are very small. However, the final result from Mayers index was 81 .

Table 9: Mayers Index for female

\begin{tabular}{|c|c|c|c|c|c|c|c|c|}
\hline \multirow[t]{2}{*}{$\begin{array}{l}\text { Terminal } \\
\text { digit }\end{array}$} & \multicolumn{2}{|c|}{$\begin{array}{l}\text { Population with } \\
\text { Terminal Digit }\end{array}$} & \multirow{2}{*}{$\begin{array}{c}\text { Ages } \\
10 \\
+(\mathrm{a}) \\
\end{array}$} & \multirow{2}{*}{$\begin{array}{c}\text { Ages } \\
20 \\
+(a) \\
\end{array}$} & \multirow[t]{2}{*}{$\begin{array}{l}\text { Blended } \\
\text { Population }\end{array}$} & \multirow[t]{2}{*}{$\begin{array}{c}(\%) \\
\text { Distribution }\end{array}$} & \multirow[t]{2}{*}{$\begin{array}{l}\text { Deviation } \\
\text { from } 10 \%\end{array}$} & \multirow{2}{*}{$\begin{array}{l}\text { Absolute } \\
\text { Deviation } \\
\text { from } 10 \%\end{array}$} \\
\hline & $\begin{array}{l}\text { Ages } 10 \\
+(\mathrm{a})\end{array}$ & $\begin{array}{c}\text { Ages } 20 \\
+(\mathrm{a}) \\
\end{array}$ & & & & & & \\
\hline 0 & 388,327 & 323,078 & 1 & 9 & 3296029 & 37.92921 & 27.92921 & 28.17 \\
\hline 1 & 36,001 & 17,847 & 2 & 8 & 214778 & 2.471568 & -7.52843 & 7.51 \\
\hline 2 & 79,175 & 39,843 & 3 & 7 & 516426 & 5.942797 & -4.0572 & 4.02 \\
\hline 3 & 51,108 & 23,324 & 4 & 6 & 344376 & 3.962924 & -6.03708 & 6.01 \\
\hline 4 & 36,741 & 14,973 & 5 & 5 & 258570 & 2.975507 & -7.02449 & 7.01 \\
\hline 5 & 243,971 & 190,610 & 6 & 4 & 2226266 & 25.61886 & 15.61886 & 15.15 \\
\hline 6 & 37,969 & 17,573 & 7 & 3 & 318502 & 3.665177 & -6.33482 & 6.31 \\
\hline 7 & 63,209 & 36,968 & 8 & 2 & 579608 & 6.669867 & -3.33013 & 3.29 \\
\hline 8 & 68,422 & 27,915 & 9 & 1 & 643713 & 7.407559 & -2.59244 & 2.55 \\
\hline 9 & 29,168 & 12,184 & 10 & 0 & 291680 & 3.356522 & -6.64348 & 6.62 \\
\hline Total & $1,034,091$ & 704,315 & & & $8,689,948$ & 100 & 0 & 87 \\
\hline \multicolumn{9}{|c|}{ Mayers' index $=87$} \\
\hline
\end{tabular}

The Myers indices for females in kebbi state resulted as follows: more age heaping under digit 0 with (27.93) was reported, followed by digit 5 with (15.62) then digit 1 with (7.5). Digit 8 was found with lowest value (2.59) which was found almost the same with that of males. 
Table 10: Mayers Index for Both Sexes.

\begin{tabular}{|c|c|c|c|c|c|c|c|c|}
\hline \multirow[t]{2}{*}{$\begin{array}{c}\text { Terminal } \\
\text { digit }\end{array}$} & \multicolumn{2}{|c|}{$\begin{array}{l}\text { Population with } \\
\text { Terminal Digit }\end{array}$} & \multirow{2}{*}{$\begin{array}{c}\text { Ages } \\
10 \\
+(a) \\
\end{array}$} & \multirow{2}{*}{$\begin{array}{c}\text { Ages } \\
20 \\
+(a) \\
\end{array}$} & \multirow[t]{2}{*}{$\begin{array}{l}\text { Blended } \\
\text { Population }\end{array}$} & \multirow[t]{2}{*}{$\begin{array}{c}(\%) \\
\text { Distribution }\end{array}$} & \multirow[t]{2}{*}{$\begin{array}{l}\text { Deviation } \\
\text { from } 10 \%\end{array}$} & \multirow{2}{*}{$\begin{array}{l}\text { Absolute } \\
\text { Deviation } \\
\text { from } 10 \%\end{array}$} \\
\hline & $\begin{array}{l}\text { Ages } 10 \\
+(a)\end{array}$ & $\begin{array}{l}\text { Ages } 20 \\
+(\mathrm{a})\end{array}$ & & & & & & \\
\hline 0 & 743,796 & 606,476 & 1 & 9 & 6202080 & 18.40211 & 8.402113 & 26.84 \\
\hline 1 & 76,783 & 37,306 & 2 & 8 & 452014 & 1.341165 & -8.65883 & 7.32 \\
\hline 2 & 162,016 & 78,641 & 3 & 7 & 1036535 & 3.07549 & -6.92451 & 3.84 \\
\hline 3 & 108,689 & 49,004 & 4 & 6 & 728780 & 2.162354 & -7.83765 & 5.67 \\
\hline 4 & 76,608 & 31,023 & 5 & 5 & 538155 & 1.596753 & -8.40325 & 6.80 \\
\hline 5 & 482,178 & 367,947 & 6 & 4 & 4364856 & 12.95091 & 2.950909 & 15.15 \\
\hline 6 & $1,711,667$ & $1,670,561$ & 7 & 3 & 16993352 & 50.42076 & 40.42076 & 5.98 \\
\hline 7 & 165,258 & 114,552 & 8 & 2 & 1551168 & 4.602451 & -5.39755 & 3.27 \\
\hline 8 & 132,952 & 60,218 & 9 & 1 & 1256786 & 3.728994 & -6.27101 & 2.54 \\
\hline 9 & 57,936 & 27,189 & 10 & 0 & 579360 & 1.719012 & -8.28099 & 6.56 \\
\hline Total & $3,717,883$ & $3,042,917$ & & & $33,703,086$ & 100 & $\mathbf{0}$ & 84 \\
\hline
\end{tabular}

Table 10 of Mayer's Index for Both Sexes results show pattern of terminal digit preference and avoidance. A strong preference for terminal digits 0 and 5, and 1 and 6 was noted. Digits 7 and 8 showed the least deviations; digit 8 showed the least followed by digit 7 .

However, it is cleared that result presented under each terminal digit $(0-9)$ for females in Table 9 has a higher digit preference than that of males in table 4.3, which indicates that there is much age heaping under every terminal digit 0 to 9 for female than in male, with this table 4.6 below was designed to extract the differences of female preference against males.

Table 11: Mayers' index difference between males and femalespreference in Kebbi State.

\begin{tabular}{|l|l|l|l|l|l|l|l|l|l|l|l|}
\hline $\begin{array}{l}\text { Terminal } \\
\text { Digit }\end{array}$ & 0 & 1 & 2 & 3 & 4 & 5 & 6 & 7 & 8 & 9 & $\begin{array}{l}\text { Mayers } \\
\text { Index }\end{array}$ \\
\hline Female & 28.17 & 7.51 & 4.02 & 6.01 & 7.01 & 15.15 & 6.31 & 3.29 & 2.55 & 6.62 & 87 \\
\hline Males & 25.43 & 7.11 & 3.66 & 5.31 & 6.59 & 15.14 & 5.63 & 3.26 & 2.53 & 6.49 & 81 \\
\hline Difference & 2.74 & 0.41 & 0.36 & 0.70 & 0.41 & 0.01 & 0.68 & 0.03 & 0.02 & 0.13 & 6 \\
\hline
\end{tabular}


Table 12:Kebbi State United Nations Age-Sex Accuracy Index for 2006 Nigeria Census

\begin{tabular}{|c|c|c|c|c|c|c|}
\hline$S / N$ & LGA & ARSM & ARSF & SRS & JS & \multirow{23}{*}{$\begin{array}{c}\text { INTERPRETATION } \\
\text { All results from } \\
\text { Joint Score (JS) } \\
\text { base on United } \\
\text { Age-Sex } \\
\text { Accuracy are } \\
>60 . \\
\text { Therefore, it is to } \\
\text { be interpreted as; } \\
\text { Grossly } \\
\text { erroneous and } \\
\text { risky to utilize } \\
\text { for any inference }\end{array}$} \\
\hline & & & & & & \\
\hline 1 & ALIERO & 36.67 & 40.89 & 18.02 & 131.63 & \\
\hline 2 & AREWA-DANDI & 32.32 & 39.39 & 16.33 & 120.69 & \\
\hline 3 & ARGUNGU & 28.96 & 41.35 & 20.51 & 131.86 & \\
\hline 4 & AUGIE & 31.35 & 42.76 & 22.04 & 140.23 & \\
\hline 5 & BAGUDO & 35.04 & 48.29 & 25.30 & 159.22 & \\
\hline 6 & BIRNIN-KEBBI & 19.65 & 34.92 & 23.07 & 123.78 & \\
\hline 7 & BUNZA & 25.94 & 41.51 & 25.03 & 142.56 & \\
\hline 8 & DANDI & 28.07 & 44.28 & 25.38 & 148.49 & \\
\hline 9 & FAKAI & 33.01 & 40.79 & 14.58 & 117.54 & \\
\hline 10 & GWANDU & 29.67 & 41.13 & 20.81 & 133.25 & \\
\hline 11 & JEGA & 31.39 & 46.77 & 26.04 & 156.28 & \\
\hline 12 & KALGO & 29.25 & 39.05 & 22.45 & 135.66 & \\
\hline 13 & KOKO/BESSE & 37.53 & 46.43 & 20.33 & 144.94 & \\
\hline 14 & MAIYAMA & 36.51 & 47.23 & 23.24 & 153.47 & \\
\hline 15 & NGASKI & 36.05 & 42.62 & 17.09 & 129.96 & \\
\hline 16 & SAKABA & 36.15 & 40.25 & 12.74 & 114.64 & \\
\hline 17 & SHANGA & 41.09 & 42.98 & 20.33 & 145.05 & \\
\hline 18 & SURU & 37.16 & 48.81 & 19.97 & 145.89 & \\
\hline 19 & WASAGU/DANKO & 33.95 & 43.94 & 20.50 & 139.44 & \\
\hline 20 & YAURI & 22.99 & 44.86 & 34.47 & 171.27 & \\
\hline 21 & ZURU & 24.11 & 28.38 & 12.72 & 90.63 & \\
\hline
\end{tabular}

Table 12 is a result from United Nations Age-Sex Accuracy Index, known as Joint Score (JS). Age Ratio Score for male (ARSM), Age Ratio Score for Female (ARSF), Sex Ratio Score (SRS) and Joint Score (JS) were analysed. Result obtained shows male age ratio are more consistent than that of females but the Joint Score (JS) could be interpreted as (Grossly erroneous and risky to utilize for any inference). Which mean too much errors are contained in the data.

Zuru has the minimal JS with (90.63), followed by Sakaba with (114.64). More errors were observed in Bagudo followed by Jega with (159.22 and 156.28) respectively. 


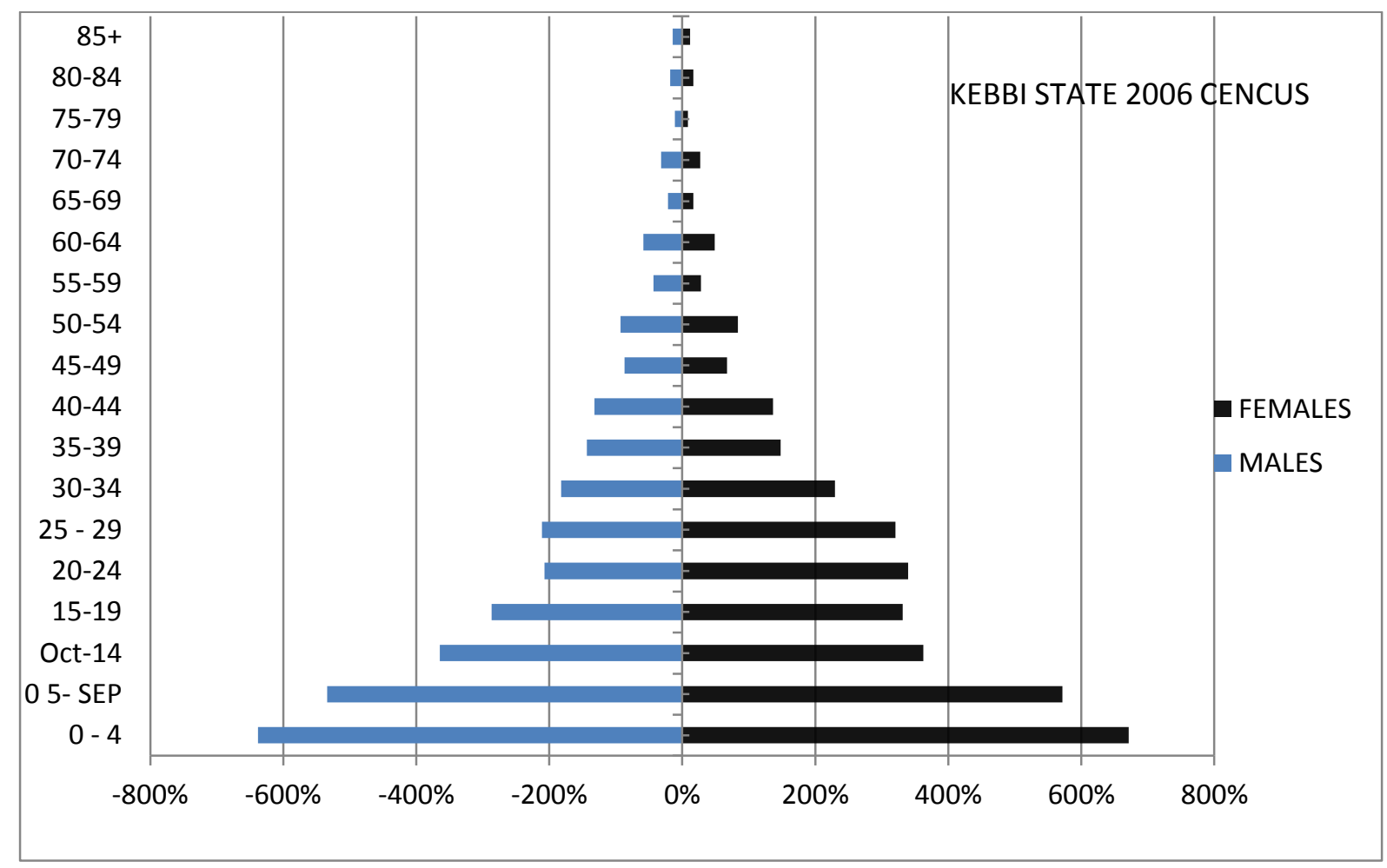

Figure 1: Population Pyramid in Kebbi State.

The pyramid shows how population of males and female tend to decrease over a period of time in Kebbi state, which could be due to death rate or migration.

Table 13: The Masculinity Proportion

\begin{tabular}{|c|c|c|c|c|c|c|}
\hline LGA & $\begin{array}{c}\text { NEVER } \\
\text { ATTENDED }\end{array}$ & $\begin{array}{c}\text { ATTENDE } \\
\text { D IN THE } \\
\text { FAST BUT } \\
\text { NOT } \\
\text { NOW }\end{array}$ & $\begin{array}{l}\text { ATTENDING } \\
\text { PRIMRY SCH }\end{array}$ & $\begin{array}{l}\text { ATTENDIN } \\
\text { G JSS }\end{array}$ & $\begin{array}{l}\text { ATTENDING } \\
\text { SSS }\end{array}$ & $\begin{array}{c}\text { ATTENDING } \\
\text { TERTIARY }\end{array}$ \\
\hline ALIERO & 83.55 & 169.86 & 143.92 & 157.39 & 205.41 & 169.28 \\
\hline AREWA-DANDI & 74.93 & 228.27 & 154.38 & 217.85 & 217.13 & 227.63 \\
\hline ARGUNGU & 75.03 & 163.94 & 136.92 & 165.62 & 173.68 & 182.13 \\
\hline AUGIE & 74.47 & 187.05 & 182.38 & 298.59 & 216.12 & 175.62 \\
\hline BAGUDO & 86.92 & 201.93 & 149.25 & 187.32 & 221.62 & 194.71 \\
\hline BIRNIN KEBBI & 74.53 & 177.13 & 136.73 & 144.55 & 166.24 & 173.61 \\
\hline BUNZA & 74.08 & 198.89 & 157.64 & 241.29 & 265.24 & 178.18 \\
\hline DANDI & 76.65 & 215.37 & 147.48 & 213.09 & 250.49 & 220.01 \\
\hline FAKAI & 90.71 & 200.82 & 137.60 & 159.45 & 150.89 & 171.52 \\
\hline GWANDU & 82.30 & 201.58 & 163.36 & 85.59 & 111.87 & 196.86 \\
\hline JEGA & 77.767 & 149.75 & 136.97 & 156.26 & 219.14 & 149.37 \\
\hline KALGO & 74.77 & 170.68 & 137.61 & 212.85 & 223.52 & 181.19 \\
\hline KOKO/BESSE & 87.78 & 171.19 & 150.31 & 218.53 & 230.77 & 185.86 \\
\hline MAIYAMA & 74.64 & 173.79 & 164.89 & 220.73 & 244.29 & 195.18 \\
\hline NGASKI & 79.98 & 212.38 & 139.03 & 248.84 & 263.77 & 212.73 \\
\hline
\end{tabular}




\begin{tabular}{|c|c|c|c|c|c|c|}
\hline SAKABA & 86.16 & 287.46 & 176.62 & 267.25 & 329.64 & 312.61 \\
\hline SHANGA & 87.65 & 219.76 & 167.37 & 242.86 & 263.05 & 197.56 \\
\hline SURU & 81.28 & 197.13 & 142.69 & 156.83 & 173.91 & 170.06 \\
\hline $\begin{array}{c}\text { WASAGU/DANK } \\
\text { O }\end{array}$ & 84.71 & 202.27 & 149.94 & 187.86 & 230.46 & 232.26 \\
\hline YAURI & 92.11 & 187.29 & 126.98 & 157.73 & 186.10 & 185.08 \\
\hline ZURU & 88.74 & 172.89 & 124.58 & 127.32 & 146.93 & 153.73 \\
\hline
\end{tabular}

In Table 13Masculinity Proportion is used to judge among the male and females literacy using 2006 census data captured base on the following factors: never attend school, attended in the fast, attending primary school, attending JSS, attending SSS and tertiary institution for both male and females as of 2006 .

We are able to discover that there are 70 to $300+$ literate males per 1 female under all factors considered (attending primary, JSS, SSS and Tertiary institution). For tertiary institution Sakaba females are more affected with the ratio of 312.61, followed by Arewa-Dandi with the ratio of 227.63 per male, for secondary also Sakaba females was found affected with the ratio of 329.64 of males per one female attending JSS, followed by Dandi with the ration of 250.49 males per one female, for child education in JSS Sakaba females (girls) were found more affected with the ratio of 250.49 , followed by Ngaski with the ratio of 248.84 of males per one female, for primary school Augie was found more affected with the ratio 182.38 , followed by Sakaba with the ratio of 176.62 males per one female.

Table 14: The Ratio of the Excess or Deficit of males to the total population

\begin{tabular}{|c|r|r|}
\hline LOCAL GOVERNMENT & Excess or Deficit of males & Excess or Deficit of males \\
\hline ALIERO & $23 / 7$ & 2.42 \\
\hline AREWA-DANDI & $-11 / 6$ & -1.17 \\
\hline ARGUNGU & $-11 / 8$ & -1.12 \\
\hline AUGIE & -1 & -0.99 \\
\hline BAGUDO & -1 & -0.98 \\
\hline BIRNIN KEBBI & $1 / 2$ & 0.49 \\
\hline BUNZA & -2 & -1.91 \\
\hline DANDI & $-11 / 4$ & -1.25 \\
\hline FAKAI & $3 / 5$ & 0.61 \\
\hline GWANDU & $-21 / 3$ & -2.36 \\
\hline JEGA & $-4 / 5$ & -0.80 \\
\hline KALGO & $-15 / 9$ & -1.55 \\
\hline KOKO/BESSE & $1 / 2$ & 0.51 \\
\hline MAIYAMA & $-31 / 6$ & -3.16 \\
\hline
\end{tabular}




\begin{tabular}{|c|r|r|}
\hline NGASKI & $-11 / 6$ & -1.18 \\
\hline SAKABA & $2 / 3$ & 0.64 \\
\hline SHANGA & $-11 / 5$ & -1.18 \\
\hline SURU & -3 & -3.00 \\
\hline WASAGU/DANKO & $-14 / 7$ & -1.57 \\
\hline YAURI & $63 / 8$ & 6.36 \\
\hline ZURU & $27 / 9$ & 2.77 \\
\hline
\end{tabular}

Every positive values indicates male excess in a given local government area council while negative values indicates males deficit (level at which males decline). In all the local governments in the state female were found excess in the population except Aliero, Birnin Kebbi, Fakai, Koko /Besse, Sakaba, Yauri and Zuru. However, when entire state (Kebbi) population is considered males are deficit with (-0.60).

\section{CONCLUSION}

The age-sex data from 2006 Nigeria population censuses are poor in quality as a result of age misreporting as seen in Table 11 and 12 respectively. However, more females are affected with age heaping and lack of educational background in all level of education attainment. Finally females out number males in the state as seen in Table 14. There is a tendency of age heaping with terminal digits ' 0 ' and ' 5 ' indicating preference for such ages, therefore people with terminal digit 7 and 8 are more reliable.

\subsection{RECOMMENDATIONS}

i. Before conducting any census in the near future, the emirs, district heads, Imams and Pastors among others should be trained the significant of census which they will in turn pass the information to their subject.

ii. Programmes that may create mass awareness and enlightening the people about the importance of accuracy in ages report through social media, schools and other important place should be provided by the government and community.

iii. To improve age reporting and accuracy, calendar of Historical Events method should be used, which relates the birth of an individual to some notable event.

iv. Birth and death registration should be mandatory at the district level which will be send to the respective local government for compilation, then to the state level for final compilation the population commission. 
v. Demographic analysis should be employed whom at a given period of time review, forecast and project the near future expectation base on the local, state and national population.

\subsection{FURTHER WORK}

We suggest that the subsequent researchers should use other data than that of census such as National population commission birth certificates, National Social Safety Net Coordinating Office (NASSCO), Local Government council and court certificate of birth. This may be more updated than the census that is used to be carried out after a decade. Also the use of questionnaires may be employed using a set of students say UG 1 to 4 in KSUSTA, Department of Mathematics or patients who open files in any given hospital in a given range of years say 2000 to 2020.

However, this will yield more result and level at which people go illiterate about their age or the ratio of male per females in a given scenario or area.

\section{REFERENCES}

1. Nwogu, E.C, Nweke C.J, and Izunobi C.H (2006)."Evaluation of age and sex data fromstates in Nigeria using the 2006 census".Department of Statistics, University of Benin, Nigeria.Benin Journal of Statistics Vol. 1, pp. 113- 122 (2018).

2. Ramachandran (1989) Urbanisation and Urban Systems in India Delhi: Oxford University Press 364 pp. Urban Studies Journal Limited, vol. 28(2), pages 290-291.

3. Serow JW, Terrie B, Waller, Wichmann RW (1997). The use of inter-censal Population stimates in political redistricting. In Kinter JH, Merrick TW, Morrison PA, Voss PR. Eds. Demographics: A Casebook for Business and Government. Rand Publication 1997; pp. 3354. Samuel D. Gosling, Wiebke Bleidorn, Ruben C. Arslan, Jaap J. A. Denissen, Peter J. 